\title{
Ellipsis
}

Volume 44

Article 30

2017

\section{From Paris with Hell}

Fabian R. Perez

University of New Orleans

Follow this and additional works at: https://scholarworks.uno.edu/ellipsis

\section{Recommended Citation}

Perez, Fabian R. (2017) "From Paris with Hell," Ellipsis: Vol. 44 , Article 30.

DOI: https://doi.org/10.46428/ejail.44.30

Available at: https://scholarworks.uno.edu/ellipsis/vol44/iss1/30

This Fiction is brought to you for free and open access by the Department of English and Foreign Languages at ScholarWorks@UNO. It has been accepted for inclusion in Ellipsis by an authorized editor of ScholarWorks@UNO. For more information, please contact scholarworks@uno.edu. 


\title{
From Paris with Hell
}

\author{
Fabian Perez
}

When boarding a plane one has only a single wish: that they don't sit next to someone who is absolutely horrible. Someone who does not smell. Someone who is not loud. Someone who doesn't use up too much space. Someone who doesn't take off their shoes, but should they take off their shoes, one hopes that vile person is wearing socks.

Well wad'ya know? I hit the jackpot. Today, the Devil himself bestowed upon me the mother lode of worthlessly horrible plane persons.

Let's face it. If you're flying alone, you're waiting and wishing and hoping and praying for a babe to sit next to you. That's just plain old facts. So imagine my horror as this Danny

DeVito/Frankenstein love child comes stumbling from the opposite wing of the plane, barreling through the middle isle like a drunken hippo, smacking unsuspecting passengers in their faces with his stench. Right away I know-this French behemoth of a beast is B lining for me. I prepare myself.

He moves like sludge, and, sludgingly, plops himself in the seat next to mine. I offer a nod and half smile; I may be a dick, but I'm not a dick. There is no reciprocation whatsoever. He just sits down and immediately starts getting comfortable in the most disgusting way. Straight from jump, he kicks off his shoes. And, for the love of everything that is holy, he is not wearing socks. His feet are exactly how you have painted in your head; that is to say, horrible. I am not in the habit of exaggerating, but I'm pretty sure I see a little farm of organisms living beneath his toenails. Organisms that are yet to be discovered. This man could be a millionaire if he only knew what miracles his foot fungi have produced.

Aside from his foot, the worst part about him is his smell. I don't even know how to describe it. Much like his feet, he seems to have concocted his very own stench unique to him. It's a hybrid pheromone; made up of decaying antelope carcasses and concentrated lizard intestines.

The guy really is somethin' special. A work of art like this comes by once in a millennia... I thank my stars that I can be so fortunate.

The portly fellow then (obviously) stretches his legs as much as he can, but not before he gets a good grab 'n pull at his groin area. After making sure he still has a dick, he places his creature of a foot into the area intended for MY feet. I decide I need to assert some kind of alpha role in this situation or this could get bad, fast. I 'accidentally' hit his foot with mine (don't worry, I'll give my shoe a good scrubbing later on), and he retracts his foot to his own feet area. Smart move, Fat French... Smart move.

And then there's his whole operation he's set up within mere seconds of sitting down. He has this bag and a book shoved into the seat's netting in front of him. On top of the book he has a banana that's rotten all to shit. Of course he does. Why on earth would he have a regular piece of fruit? Additionally he has some sort of... dish towel? Yeah, I'll just say it's that because God knows 
what it is. It's filthy and it is sticking out from between the banana and book. The wildebeest has discovered the use of tools! He is using the weight of the banana to trap the dirty wash cloth so it will not fall. He is learning... He is evolving...

Beneath his net of bullshit, he has a bag, some other bullshit, and his shoes, all shoved in an Idont-give-a-shit-about-anything kind of manner at his feet. His personal effects remind me of what you might find in a crack head's stolen shopping cart: All of it he needs, while all of it is crap.

He checks his groin area again to make sure everything's there. A pull here, a tug there... Yep. Seems like it's all there. Smart man, Mr. French, you can never be too sure these days. At any point in time I fully expect this walking ass-fart sitting next to me to turn his head and expel a $31 \mathrm{~b}$ loogie at the window for no reason at all.

He caps off his heroic feat of baboon-ism by feeding his family. Oh yeah, his family is on board. His family of five. His family seems normal for the most part, though. And, by "normal", I mean they aren't space creatures from the planet Squirglebirth and of the humanoid(ish) race that is Snaggletooth, like the paternal member of their household. Anyway, he chooses to feed his family like any living gargoyle would. He goes in the overhead bin and produces an entire loaf of bread. $\mathrm{Hm}$. That's kind of weird.

But hey, at least he isn't feeding his family something that you definitely shouldn't be eating on a plane, something that could permeate an entire cabin and infiltrate the nostrils of all on board, something like fish. Yeah, that's good. At least he isn't feeding his family fish, ha! Now that would be a real disaster- Wait. Dear God, no.

Almighty up above, what have I done in my past lives to deserve this? Have I killed?

Have I killed many?

Was I Hitler?

\section{WAS I HITLER!?}

I had to have been, because Jabba the Hutt is feeding his family fish sandwiches. He is making five fish sandwiches. On a plane. That's worse than eating a pickle in a movie theater. I'm speechless. I feel like standing up and giving the French Jabba here a round of applause. This man is a national treasure. Take a bow, sir.

\section{Take a glorious, fucking bow.}




\section{Dear Mr. Morbidly Obese Aborted Whale Fetus,}

I choose to believe you have never encountered any kind of social situation whatsoever. In my heart of hearts, I believe you've been trapped underground for your entire life. I believe you and your family have been fending for your lives underneath the streets of Paris, wandering the sewers, fighting off the demons and unworldly creatures that have escaped the ghostly corridors of the catacombs, all the while so desperately trying to find an escape to the above world. I can see it. I can see it as vivid as a dream from which I just awoke. I see you standing beneath a manhole cover, and there's a tiny slit in the manhole, from which you can see an entire universe. You cannot move the cover, but God knows you've tried. You've tried and your family helplessly watches you, and every time you try, you fail, and you feel beaten; beaten as a man that you cannot exert the physical strength, and beaten because you cannot provide for your family. You try making yourself heard, screaming through the slit. You scream as loud as your chest will allow, and then you scream some more. Sadly, your words are like whispers, for they fall soft on the loud ears of Paris. Your family tries to console you, but just like every other time, you dismiss it. You see their eyes move from comfort, to sadness, and eventually to pity. The pity is more than you can bear, and most days it swallows you.

But sometimes, after they've fallen asleep in the dark and scary, you go back to that manhole cover. You look through that opening and you see your universe. You see the shuffling of shoes and the chatter of children. You hear laughter and you hear sadness. No faces can be made out, as the universe above moves much too fast. All you hear are the milliseconds of strangers' lives as they cross over you like you are nothing. As much as you yearn to break through and walk amongst the rest of them, you also hate the universe you see. Envy and desire turns to frustration, and ultimately, anger. You love the world you see above, and you despise it.

Regardless, you try and try every day. And every day you fail. Until one day, as you retreat back to the living quarters beneath the dripping pipes and scattering roaches, your youngest daughter, a fille of only thirteen, approaches you. She grabs your arm and hands you a note. She says nothing; only looks at you and smiles sadly. You open the note and it reads:

\section{I am here.}

That is all. Three words. She has grown so tired of seeing you defeated day after day that she feels a simple reminder of love is of importance. You smile. That child, oh how you marvel her.

That night you have a dream. A dream that changes you and your family's lives forever. You dream a man is crying in the above world. He has lost his family in a terrible car accident. You dream he has lost all hope until a young girl walks up, your daughter. She sees him sad, and she hands him a note. The same note she gave you. The man smiles back at the girl, and he remembers happiness. He turns his eyes up to the streets of Paris, the same universe you fight so relentlessly to be a part of - and the dream goes to black.

You wake up brilliantly, and the idea robs you.

On the streets of Paris, just near the manhole you fight every night, a young boy sits on a bench outside of a laundromat. He is playing with a toy truck while his mother is in inside the laundromat. He follows the concave of the wooden bench and hurdles the truck against the slope. 
With big eyes, He watches as the truck flies through the air. He has done this at least a dozen times, regardless of his mother's scolding, "Arrête ça!" Stop that!

This time his trajectory is off, not that it's ever really 'on', and his truck lands in the middle of the street, wheel-side down, by a sewer's manhole. He looks over his shoulder to make sure his mother isn't looking, as this would earn another scolding, maybe even a belt to the butt, if she caught him in the street. The boy dreads the belt to the butt, but he quickly calculates risk to reward, and decides an adventure off the sidewalk for a rescue mission of his truck is worth it.

As he makes his way towards the street, he stops. Just as he is about to take his first step off the sidewalk, he sees something tiny fall into the bed of the truck. It seems to have dropped out of thin air... Now all rationality is gone. He needs that truck. There is a far-off voice in his head telling him to look both ways. He ignores the voice. The boy makes his way towards the truck, his anticipation peaking. He bends down and picks up the alien object that jumped in his toy.

It seems to be a balled up piece of paper, a real dirty piece of paper. Both grossed out and intrigued, the boy unravels the paper. The tiny piece of balled up paper unfurls to the size of his palm. The piece of paper is a note. The note says only three words.

Down in the sewers that maze beneath for miles, you wait. You don't worry whether or not your message will be read. You have not one inkling of fear that you will not be saved. You have no clue that a nine-year-old boy has found your message. You have no clue that he has imagined your exact predicament. You have no clue that he has already rushed to his mom to rescue the man beneath the street. You have no clue that the child will not leave the laundromat until his mother lifts the manhole. Your mind does not wander. Something in you tells you the note is a gift from God. Maybe God himself spoke to you. Maybe you just know because your daughter's eyes told you.

I say it comes down to the boy being an only child, and his imagination getting the better of him, as an only child's imagination does. The boy throws such a tantrum outside the laundromat that he catches the attention of two nearby police men. The mother tells the two cops the fable her son has written in his head. The police man kneels down and knocks on the manhole cover. You'll find out much later that the kneeling police man is an only child.

You are saved. Your family is saved. In the universe above, you hear calamity ensue. You exchange a look with your wife that makes you feel as if you're floating. Is this real, you think to yourself. Your family holds each other as the cover is lifted. It is night when you breathe fresh air for the first time, and when the cover is lifted you are blinded. Not from the bulbs of cameras or flashlights, but by the stars. You see stars for the first time and you are stunned. For a moment you do not move with your family as the ladder is handed down. You simply stand. You stand in amazement as a single tear travels the length of your cheek. It is more beautiful than anything you imagined the Above to be.

The next day you are seated on a plane. You are told you will be traveling to a place called America. There, you and your family will be meeting with some important people who would like to learn about you and your story.

On the plane you sit next to a young man named Fabi. Fabi does not know you have been a functional member of society for literally one day. He notices only the grotesque features you 
display. He does not know what you have gone through, and the odds are in his favor that he will never go through anything of the sort. Fabi then makes up a story trying to justify why you are so strange. He becomes so enveloped in his story that he spends nearly 5 hours coming up with the wildest and most heartbreaking scenario imaginable. He thinks up a man and a family who have nothing but themselves, and a three-worded note that created a future.

But that note was never written. And that man beneath the world never existed. There was never a story of true heroism and there was never anything that ever existed to make for a passable excuse to deem the life you live excusable. The only thing that ever existed was you, you insufferable piece of dog shit that somehow takes human form. That's what you are. You are a piece of canine feces that shape-shifts to man. You. You in seat 20J. Here to torment 20K into oblivion.

I will never forget you, Fat French. You will haunt me until my dying day. But it is on that day that I will meet you in hell. I planned on going to the more heavenly variety when I left this world, but seeing as though you have ruined my life, I have made other plans. I will commit every sin under the sun if need be, all to reach hell, to reach you. As for your final destination, I have no doubt in my mind that you will already be there. Yes, I know where you're going. And I now know where I'm going. I'm coming for you. You ruined me, Parisian. But I will have the last word. And I will have it in hell. 